\title{
Overweight/obesity in young adulthood interacts with aspects of EBV infection in MS etiology
}

Anna Karin Hedström, MD, PhD, Nicole Brenner, PhD, Julia Butt, PhD, Jan Hillert, MD, PhD, Tim Waterboer, PhD, Tomas Olsson, MD, PhD,* and Lars Alfredsson, PhD*

Neurol Neuroimmunol Neuroinflamm 2021;8:e912. doi:10.1212/NXI.0000000000000912

\section{Abstract}

\section{Objective}

Because obesity affects the cellular immune response to infections, we aimed to investigate whether high body mass index (BMI) in young adulthood and high Epstein-Barr nuclear antigen 1 (EBNA-1) antibody levels interact with regard to MS risk. We also aimed at exploring potential 3-way interactions between BMI at age 20 years, aspects of Epstein-Barr virus (EBV) infection (high EBNA-1 antibody levels and infectious mononucleosis [IM] history, respectively) and the human leukocyte antigen (HLA)-DRB1*15:01 allele.

\section{Methods}

Using Swedish population-based case-control studies (5,460 cases and 7,275 controls), we assessed MS risk in relation to interactions between overweight/obesity at age 20 years, IM history, EBNA-1 levels, and HLA-DRB1*15:01 status by calculating ORs with $95 \%$ CIs using logistic regression. Potential interactions were evaluated on the additive scale.

\section{Results}

Overweight/obesity, compared with normal weight, interacted significantly with high (>50th percentile) EBNA-1 antibody levels (attributable proportion due to interaction 0.2 , 95\% CI $0.1-0.4$ ). The strength of the interaction increased with higher category of EBNA-1 antibody levels. Furthermore, 3-way interactions were present between HLA-DRB1*15:01, overweight/ obesity at age 20 years, and each aspect of EBV infection.

\section{Conclusions}

With regard to MS risk, overweight/obesity in young adulthood acts synergistically with both aspects of EBV infection, predominantly among those with a genetic susceptibility to the disease. The obese state both induces a chronic immune-mediated inflammation and affects the cellular immune response to infections, which may contribute to explain our findings.

\author{
Correspondence \\ Dr. Hedström
}

anna.hedstrom@ki.se 


\section{Glossary}

BMI = body mass index; EBV = Epstein-Barr virus; EIMS = Epidemiological Investigation of Multiple Sclerosis; EIRA = Epidemiological Investigation of Rheumatoid Arthritis; EPNA-1 = Epstein-Barr nuclear antigen 1; GEMS = Genes and Environment in Multiple Sclerosis; HLA = human leukocyte antigen; IM = infectious mononucleosis; $\mathbf{M F I}=$ median flourescence intensity.

MS is a multifocal inflammatory disease of the CNS with underlying genetic and environmental factors. Variations in the human leukocyte antigen (HLA) region influence susceptibility to MS with the main effect originating from the Class II DRB1 gene. ${ }^{1}$ Environmental and lifestyle factors increasing MS risk include smoking, ${ }^{2}$ low sun exposure, ${ }^{3}$ low vitamin D status, ${ }^{4}$ high body mass index (BMI) ${ }^{5,6}$ and Epstein-Barr virus (EBV) infection. ${ }^{7}$ High BMI during adolescence and young adulthood, but not at the time of MS onset, has repeatedly been associated with an increased risk of developing MS. ${ }^{5,6}$ The risk increases in a dose-dependent manner. ${ }^{6}$

Elevated Epstein-Barr nuclear antigen 1 (EBNA-1) antibody levels and infectious mononucleosis (IM) history are aspects of EBV infection that seem to represent separate risk factors for $\mathrm{MS}^{7}$ An additive interaction has been observed between high BMI at age 20 years and a history of $\mathrm{IM}^{8}{ }^{8}$ but whether a similar interaction occurs between obesity and elevated EBNA-1 antibody levels is unclear.

Because most environmental and lifestyle risk factors for MS seem to act synergistically with the main genetic risk factor for MS, the HLA-DRB1 ${ }^{*} 15: 01$ allele, ${ }^{7,9}$ it is also of interest to study both separate and joint effects of these factors.

Using Swedish population-based case-control studies, comprising 5,460 cases and 7,275 controls, we thus aimed to investigate potential 2- and 3-way interactions between BMI at age 20 years, aspects of EBV infection, and presence of DRB1 15:01.

\section{Methods}

\section{Study design and study subjects}

We used 2 Swedish population-based case-control studies on environmental and genetic risk factors for MS: Epidemiological Investigation of Multiple Sclerosis (EIMS) and Genes and Environment in Multiple Sclerosis (GEMS). The study population comprised the general population aged 16-70 years. In EIMS, newly diagnosed cases of MS were recruited from neurology clinics, including all university hospitals in Sweden. Cases were diagnosed by a neurologist according to the 2005 or $2010 \mathrm{McD}$ onald criteria. ${ }^{10,11}$ For each case, we randomly selected 2 controls from the national population register, frequency matched by age in 5-year age strata, sex, and residential area. The participants were included between April 2005 and June 2015.
In GEMS, we identified prevalent cases of MS from the Swedish National MS Registry. ${ }^{12}$ All cases in both studies fulfilled the 2005 or $2010 \mathrm{McDonald}$ criteria. ${ }^{10,11}$ One control for each case was selected in the same manner as in EIMS. All participants were recruited between November 2009 and November 2011.

To increase the number of controls, we also used controls from the Epidemiological Investigation of Rheumatoid Arthritis (EIRA), which is a population-based case-control study with incident cases of rheumatoid arthritis, designed in the same manner as EIMS, using a similar study population in southern and middle parts of Sweden. The EIRA controls were not matched on age, sex, or residential area to MS cases in either EIMS or GEMS. The study has been described in detail elsewhere. $^{13}$

\section{Data collection}

We used a standardized questionnaire to collect information regarding environmental exposures and lifestyle factors. The response rate was $93 \%$ for cases and $73 \%$ for controls in EIMS, $82 \%$ for cases and $66 \%$ for controls in GEMS, and $75 \%$ for controls in EIRA.

In all studies, participants were asked whether they had ever had IM, and if yes, at what age the infection occurred. Those who were unsure regarding IM history were excluded. For each case in EIMS and GEMS, the clinical onset of disease was defined as the index year. The corresponding controls were given the same index year. IM history was considered before the index year and was recorded as either reported infection or no infection.

Self-reported information was obtained regarding current body height and body weight at age 20 years. Subjects younger than 20 years at the index year were excluded. Using current height, we calculated BMI at age 20 years by dividing weight in kilograms by height in meters squared.

All participants were asked to provide a blood sample and those who did not donate blood were excluded from the main analysis. The number of study subjects in each study is presented in table 1 .

\section{Potential confounding variables}

Ancestry was dichotomized into Swedish or non-Swedish. Educational level was categorized into no postsecondary education, postsecondary education, or university degree. Based on 3 questions about exposure to ultraviolet radiation where each 
Table 1 Number of cases and controls included in the study

\begin{tabular}{|c|c|c|c|c|c|}
\hline Study & $\begin{array}{l}\text { Included in } \\
\text { the study }\end{array}$ & $\begin{array}{l}\text { Disease onset } \\
20 \text { y or older }\end{array}$ & $\begin{array}{l}\text { Data on BMI } \\
\text { at age } 20 y \\
\text { and IM history }\end{array}$ & $\begin{array}{l}\text { Data on HLA } \\
\text { genotype. Data } \\
\text { set for analysis }\end{array}$ & $\begin{array}{l}\text { Data on EBNA-1 } \\
\text { antibody levels. } \\
\text { Data set for analysis }\end{array}$ \\
\hline \multicolumn{6}{|l|}{ EIMS } \\
\hline Cases & 2,880 & 2,740 & 2,309 & 1,729 & 1,681 \\
\hline Controls & 6,122 & 5,766 & 4,851 & 2,494 & 2,114 \\
\hline \multicolumn{6}{|l|}{ GEMS } \\
\hline Cases & 6,156 & 5,588 & 4,385 & 3,731 & 3,139 \\
\hline Controls & 5,408 & 4,893 & 3,987 & 2,941 & 2,889 \\
\hline \multicolumn{6}{|l|}{ EIRA } \\
\hline Controls & 5,935 & 5,892 & 4,907 & 1,840 & - \\
\hline \multicolumn{6}{|l|}{ Total } \\
\hline Cases & 9,036 & 8,328 & 6,694 & 5,460 & 4,820 \\
\hline Controls & 17,465 & 15,555 & 13,745 & 7,275 & 5,003 \\
\hline
\end{tabular}

Abbreviations: $\mathrm{BMI}=$ body mass index; EIMS = Epidemiological Investigation of Multiple Sclerosis; EIRA = Epidemiological Investigation of Rheumatoid Arthritis; EPNA-1 = Epstein-Barr nuclear antigen 1; GEMS = Genes and Environment in Multiple Sclerosis; HLA = human leukocyte antigen; IM = infectious mononucleosis.

answer alternative was given a number ranging from 1 (the lowest exposure) to 4 (the highest exposure), we constructed an index by adding the numbers together and thus acquired a value between 3 and $12 .{ }^{14}$ Sun exposure was then dichotomized based on the 25th percentile among controls. Smokers were dichotomized into ever or never smokers. Exposure to passive smoking at home or at work on a daily basis was dichotomized into ever or never exposed. Alcohol consumption was categorized into the following subgroups based on the amount of alcohol intake per week: low consumption $(<50 \mathrm{~g} / \mathrm{wk}$ for women and $<100 \mathrm{~g} / \mathrm{wk}$ for men), moderate consumption $(50-112 \mathrm{~g} / \mathrm{wk}$ for women and $100-168$ $\mathrm{g} / \mathrm{wk}$ for men), and high consumption (>112 g/wk for women and $>168 \mathrm{~g} / \mathrm{wk}$ for men). The cutoffs were the same as those used by Statistics Sweden, a government agency that produces official statistics.

\section{Standard protocol approvals, registrations, and patient consents}

Ethical approval for both EIMS and GEMS was obtained from the Regional Ethical Review Board at Karolinska Institutet. All participants gave their written informed consent.

\section{Genotyping and measurement of EBNA-1 antibody levels}

In EIMS and GEMS, HLA-DRB1 and HLA-A alleles were determined at 4-digit resolution. Genotyping was performed on the MS replication chip, ${ }^{15}$ which is based on an Illumina exome chip, and HLA was then imputed with HLA*IMP:02. ${ }^{16}$ In EIRA, HLA$D R B 1$ genotypes were obtained as previously described. ${ }^{13}$ In EIMS and GEMS, we used multiplex serology to detect immunoglobulin $\mathrm{G}$ antibodies against the EBNA-1 peptide segment (aa 385-420), ${ }^{17,18}$ which has been identified as the primary
EBNA-1 fragment associated with MS risk. ${ }^{19}$ Dual-laser flowbased detection was used to quantify the antibodies in median flourescence intensity (MFI) units. We dichotomized EBNA-1 antibody levels based on the median seroreactivity among controls (5,620 MFI) into groups with high and low EBNA-1 antibody levels. ${ }^{7}$ To study whether the potential interaction between obesity at age 20 years and high EBNA-1 antibody levels was affected by increasing EBNA-1 levels, we also divided the participants into 4 groups based on the seroreactivity among controls at the 50th, 75th, and 95th percentiles.

\section{Statistical analysis}

All analyses were adjusted for study, age, sex, residential area, ancestry, smoking, and when appropriate for $A^{*} 02: 01$, $D R B 1^{*} 15: 01$, and IM history. Adjustments were also made for educational level, sun exposure habits, passive smoking, and alcohol consumption, but these factors had minor influence on the results and were not retained in the final analyses.

Subjects characterized by BMI at age 20 years, EBNA- 1 and IM status were compared with regard to MS risk, by calculating ORs with 95\% CIs using unconditional logistic regression models. ${ }^{20}$ Potential interactions were analyzed using departure from additivity of effects as criterion of interaction. Synergistic effects between overweight/obesity at age 20 years and each aspect of EBV infection were evaluated by calculating the attributable proportion due to interaction and relative excess risk due to interaction together with $95 \% \mathrm{CI}^{21,22}$ Superadditive associations between overweight/obesity at age 20 years, $H L A-D R B 1^{*} 15$, and a history of IM (or high EBNA1 antibody levels) were calculated by comparing the joint effect of the 3 risk factors to the situation when each one acts 
Table 2 Characteristics of cases and controls, overall and by study

\begin{tabular}{|c|c|c|c|c|c|c|c|}
\hline & \multicolumn{2}{|l|}{ Overall } & \multicolumn{2}{|l|}{ EIMS } & \multicolumn{2}{|l|}{ GEMS } & \multirow{2}{*}{$\frac{\text { EIRA }}{\text { Controls }}$} \\
\hline & Cases & Controls & Cases & Controls & Cases & Controls & \\
\hline Women, n (\%) & $4,022(74)$ & $5,520(76)$ & $1,263(73)$ & $1,892(76)$ & $2,759(74)$ & $2,287(78)$ & $1,341(73)$ \\
\hline Men, n (\%) & $1,438(26)$ & $1,755(24)$ & $466(27)$ & $602(24)$ & $972(26)$ & $654(22)$ & $499(27)$ \\
\hline Swedish origin, $\mathrm{n}(\%)$ & $4,454(82)$ & $5,949(82)$ & $1,385(80)$ & $1,929(77)$ & $3,069(82)$ & $2,436(83)$ & $1,584(86)$ \\
\hline BMI at age $20 \mathrm{y}, \mathrm{kg} / \mathrm{m}^{2}$, mean (SD) & $22.0(3.5)$ & $21.6(3.0)$ & $22.6(3.8)$ & $21.8(3.1)$ & $21.7(3.3)$ & $21.5(2.9)$ & $21.5(2.8)$ \\
\hline $\mathrm{BMI} \geq 25 \mathrm{~kg} / \mathrm{m}^{2}, \mathrm{n}(\%)$ & $719(13)$ & $686(9.4)$ & $304(18)$ & $265(11)$ & $415(11)$ & $362(8.5)$ & $170(9.2)$ \\
\hline A history of IM, $n(\%)$ & $877(16)$ & $616(8.5)$ & $330(19)$ & $267(11)$ & $547(15)$ & $223(7.6)$ & $126(6.9)$ \\
\hline Ever smoking, n (\%) & $3,132(57)$ & $3,688(51)$ & $934(54)$ & $1,138(46)$ & $2,198(59)$ & $1,466(50)$ & $1,084(59)$ \\
\hline HLA-DRB1*15:01, n (\%) & $3,145(58)$ & $2,069(28)$ & $955(55)$ & $688(28)$ & $2,190(59)$ & $866(29)$ & $515(28)$ \\
\hline HLA-A*02:01, n (\%) & 2,355 (43) & $2,986(55)$ & $719(42)$ & $1,354(54)$ & $1,636(44)$ & $1,632(55)$ & - \\
\hline Median EBNA-1 IgG (MFI) & 7,828 & 5,601 & 7,807 & 5,448 & 7,855 & 5,699 & - \\
\hline Total & 5,460 & 7,275 & 1,729 & 2,494 & 3,731 & 2,941 & 1,840 \\
\hline
\end{tabular}

Abbreviations: $\mathrm{BMI}=$ body mass index; EIMS = Epidemiological Investigation of Multiple Sclerosis; EIRA = Epidemiological Investigation of Rheumatoid Arthritis; EPNA-1 = Epstein-Barr nuclear antigen 1; GEMS = Genes and Environment in Multiple Sclerosis; HLA = human leukocyte antigen; IgG = immunoglobulin G; IM = infectious mononucleosis; MFI = median flourescence intensity.

separately, using the total relative excess risk due to interaction. $^{18}$

As sensitivity analyses, we performed the interaction analyses stratified by study. We also conducted all analyses restricted to include subjects with data on HLA alleles as well as antiEBNA-1 antibody levels. These analyses were further adjusted for $D R B 1^{*} 15: 01$ when appropriate and for the following alleles from other HLA regions that have been shown to influence MS risk independently of $D R B 1^{*} 15: 01$ status ${ }^{1}$ : $D R B 1^{*} 03: 01, D R B 1^{*}$ 13:03, $D R B 1^{*} 08: 01, B^{*} 44: 02, B 38: 01$, B44:02, DQA $1^{*}$ 01:01, DQB1*03:02, and $D Q B I^{*} 03: 01{ }^{1}{ }^{1} \mathrm{Ho}-$ mozygote correction was made for $D R B 1^{*} 15: 01, D R B 1^{*} 03$ : 01 , and $A^{*} 02: 01$. All analyses were conducted using Statistical Analysis System version 9.4.

\section{Data availability}

Anonymized data will be shared by request from any qualified investigator who wants to analyze questions that are related to the published article.

\section{Results}

Among the cases, the mean age at disease onset was 33.7 (SD 10.4) years. The majority of cases in EIMS were recruited within 1 year after the diagnosis, and the questionnaires were completed after a median of 2.0 years following MS onset. In GEMS, the median duration from disease onset to study inclusion was 18.0 (SD 11.7) years. Selected characteristics of cases and controls are presented in table 2. Characteristics were similar between those who donated blood and those who did not (table e-1, links.lww. com/NXI/A374).

\section{BMI at age 20 years and a history of IM}

Overweight/obesity at age 20 years and a history of IM synergistically increased the risk of MS. Overall, IM history among nonoverweight subjects was associated with a $90 \%$ increased risk of MS, whereas overweight/obesity at age 20 years $\left(\mathrm{BMI} \geq 25 \mathrm{~kg} / \mathrm{m}^{2}\right)$ with no history of IM was associated with a $40 \%$ increased MS risk. Compared with nonoverweight subjects without IM history, the combination of the 2 risk factors increased MS risk 5-fold.

\section{BMI at age 20 years and EBNA-1 status}

A similar but less pronounced interaction was observed between BMI at age 20 years and high EBNA-1 antibody levels. The interaction became stronger with increasing category of EBNA-1 antibody levels, using a variety of different cut-points (table 3). Our findings remained significant when subjects with a history of IM were excluded.

\section{DRB1*15 status, BMI at age 20 years, and aspects of EBV infection}

With regard to MS risk, 2-way interactions were present between $D R B 1^{*} 15: 01$ and overweight/obesity at age 20 years, between $D R B 1^{*} 15: 01$ and each aspect of EBV infection, and between overweight/obesity at age 20 years and each aspect of EBV infection (tables 4 and 5).

Furthermore, significant 3-way interactions on the additive scale were observed between $D R B 1^{*} 15: 01, \mathrm{BMI}$ at age 20 years, and each aspect of EBV infection (IM history and high 
Table 3 OR with $95 \% \mathrm{Cl}$ of developing MS for subjects with different combinations of BMI at age 20 years and EBNA-1 antibody levels

\begin{tabular}{|c|c|c|c|c|c|c|}
\hline & EBNA-1 category & $\mathrm{Ca} / \mathrm{co}^{\mathrm{a}}$ & OR $(95 \% \mathrm{Cl})^{\mathrm{b}}$ & OR $(95 \% \mathrm{CI})^{c}$ & $\mathrm{AP}(95 \% \mathrm{CI})$ & RERI (95\% CI) \\
\hline \multicolumn{7}{|c|}{ BMI at age $20 \mathrm{y}, \mathrm{kg} / \mathrm{m}^{2}$} \\
\hline$<25$ & $<50$ th percentile & $1,004 / 2,264$ & 1.0 (reference) & 1.0 (reference) & & \\
\hline$\geq 25$ & $<50$ th percentile & $135 / 237$ & $1.3(1.1-1.7)$ & $1.4(1.1-1.8)$ & & \\
\hline$<25$ & $\geq 50$ th percentile & $3,194 / 2,263$ & $3.1(2.9-3.5)$ & $2.8(2.5-3.0)$ & & \\
\hline$\geq 25$ & $\geq 50$ th percentile & $487 / 239$ & $4.7(3.9-5.5)$ & $4.1(3.4-4.8)$ & 0.2 (0.1 to 0.4$)$ & 1.4 (1.1 to 1.8$)$ \\
\hline \multicolumn{7}{|c|}{ BMI at age $20 \mathrm{y}, \mathrm{kg} / \mathrm{m}^{2}$} \\
\hline$<25$ & $<50$ th percentile & $1,004 / 2,264$ & 1.0 (reference) & 1.0 (reference) & & \\
\hline$\geq 25$ & $<50$ th percentile & $135 / 237$ & $1.5(1.1-1.7)$ & $1.5(1.1-1.8)$ & & \\
\hline$<25$ & 50th-75th percentile & $1,198 / 1,130$ & $2.4(2.2-2.7)$ & $2.1(1.9-2.4)$ & & \\
\hline$\geq 25$ & 50th-75th percentile & $163 / 120$ & $3.2(2.5-4.1)$ & $2.7(2.1-3.5)$ & $0.02(-0.3$ to 0.3$)$ & $0.1(-0.2$ to 0.3$)$ \\
\hline \multicolumn{7}{|c|}{ BMI at age $20 \mathrm{y}, \mathrm{kg} / \mathrm{m}^{2}$} \\
\hline$<25$ & $<50$ th percentile & $1,004 / 2,264$ & 1.0 (reference) & 1.0 (reference) & & \\
\hline$\geq 25$ & $<50$ th percentile & $135 / 237$ & $1.3(1.0-1.6)$ & $1.4(1.1-1.8)$ & & \\
\hline$<25$ & 75th-95th percentile & $1,481 / 903$ & $3.7(3.3-4.1)$ & $3.0(2.7-3.4)$ & & \\
\hline$\geq 25$ & 75th-95th percentile & $236 / 98$ & $5.7(4.4-7.3)$ & $4.6(3.6-6.0)$ & 0.3 (0.1 to 0.5$)$ & 1.5 (1.1 to 2.2$)$ \\
\hline \multicolumn{7}{|c|}{ BMI at age $20 \mathrm{y}, \mathrm{kg} / \mathrm{m}^{2}$} \\
\hline$<25$ & $<50$ th percentile & $1,004 / 2,264$ & 1.0 (reference) & 1.0 (reference) & & \\
\hline$\geq 25$ & $<50$ th percentile & $135 / 237$ & $1.3(1.1-1.7)$ & $1.4(1.1-1.8)$ & & \\
\hline$<25$ & $>95$ th percentile & $515 / 230$ & $4.8(4.0-5.7)$ & $4.0(3.3-4.8)$ & & \\
\hline$\geq 25$ & >95th percentile & $85 / 21$ & $9.2(5.7-14.9)$ & $7.3(4.4-12.0)$ & 0.4 (0.1 to 0.7$)$ & 2.8 (0.9 to 6.5$)$ \\
\hline \multicolumn{7}{|c|}{$\begin{array}{l}\text { Abbreviations: AP = attributable proportion due to interaction; BMI = body mass index; EPNA-1 = Epstein-Barr nuclear antigen 1; RERI = relative excess risk due } \\
\text { to interaction. } \\
\text { a Number of exposed cases and controls. } \\
\text { b Adjusted for study, age, sex, residential area, ancestry, and smoking. } \\
\text { 'Adjusted for study, age, sex, residential area, ancestry, smoking, IM history, } A * 02: 01 \text {, and } D R B 1 * 15: 01 \text {. }\end{array}$} \\
\hline
\end{tabular}

EBNA-1 antibody levels, respectively) (tables 4 and 5). The results presented in tables 4 and 5 are illustrated in the figure.

All main findings remained significant when the analyses were stratified by study (EIMS and GEMS). The overall interaction between BMI at age 20 years and high EBNA-1 antibody levels, stratified by study, is presented in table e-2, links.lww. com/NXI/A374. All findings also remained significant when we performed the analyses restricted to subjects with complete data on HLA alleles and EBNA-1 antibody levels (data not shown).

\section{Discussion}

According to our findings, overweight/obesity in young adulthood acts synergistically with both a history of IM and high EBNA-1 antibody levels. The effect estimates for the interaction between BMI at age 20 years and EBNA-1 antibody levels became stronger with increasing category of antibody levels. Furthermore, significant 3-way interactions on the additive scale were observed between $D R B 1^{*} 15: 01, B M I$ at age 20 years, and each aspect of EBV infection.

Adipose tissue is considered an active endocrine organ that results in a strong proinflammatory environment in subjects with obesity. Inflammatory mediators such as interleukin 6, C-reactive protein, and tumor necrosis factor alpha significantly correlate with BMI. Obesity has been associated with a decreased number of regulatory $\mathrm{T}$ and $\mathrm{B}$ subsets, expansion of Th17 cells, and promotion of autoantibodies, which may lead to breakdown of self-tolerance and promote the onset and progression of autoimmune responses. ${ }^{23-25}$ Obesity contributes to the development of a number of inflammatory and autoimmune diseases, including $M{ }^{26,27}$ Obesity also results in a state of 
Table 4 OR with $95 \% \mathrm{Cl}$ of developing MS for subjects with different combinations of $D R B 1 * 15: 01$ status, BMI at age 20 years, and IM history

\begin{tabular}{|c|c|c|c|c|c|c|}
\hline BMI at age $20 \mathrm{y}, \mathrm{kg} / \mathrm{m}^{2}$ & A history of IM & $D R B 1 * 15: 01$ & $\mathrm{ca} / \mathrm{co}^{\mathrm{a}}$ & OR $(95 \% \mathrm{CI})^{\mathrm{b}}$ & RERI $(95 \% \mathrm{CI})$ & $\overline{\text { TotRERI }(95 \% \mathrm{Cl})}$ \\
\hline$<25$ & - & - & $1,698 / 4,305$ & 1.0 (reference) & & \\
\hline$\geq 25$ & - & - & $239 / 465$ & $1.4(1.1-1.6)$ & & \\
\hline$<25$ & + & - & $313 / 399$ & $2.0(1.7-2.3)$ & & \\
\hline$\geq 25$ & + & - & $65 / 37$ & $4.5(2.9-7.0)$ & $2.1(0.5-3.7)$ & \\
\hline$<25$ & - & + & $2,313 / 1,715$ & $3.4(3.1-3.7)$ & & \\
\hline$\geq 25$ & - & + & $333 / 174$ & $4.8(3.9-5.9)$ & $1.5(0.3-2.6)$ & \\
\hline$<25$ & + & + & $417 / 170$ & $6.4(5.2-7.8)$ & $2.4(1.0-3.8)$ & \\
\hline$\geq 25$ & + & + & $82 / 10$ & $22.2(10.7-43.6)$ & & $15.4(0.8-30.1)$ \\
\hline
\end{tabular}

Abbreviations: BMI = body mass index; EPNA-1 = Epstein-Barr nuclear antigen 1; RERI = relative excess risk due to interaction; TotRERI = total relative excess risk due to interaction; controls from EIRA were included.

${ }^{a}$ Number of exposed cases and controls.

${ }^{\mathrm{b}}$ Adjusted for study, age, sex, residential area, ancestry, and smoking.

immunodeficiency, including altered lymphocyte functionality, rendering obese people more susceptible to infections. ${ }^{28}$ Immunodeficiency due to obesity may thus alter immune responses to pathogens and increase the risk of an inflammatory response directed at self-antigens. Several environmental factors that predispose to MS, including both high BMI and EBV infection, seem to act long before the clinical onset of the disease. This suggests a sensitive period for lifestyle and environmental factors in MS or may reflect the existence of a prodromal phase for the disease.

Both EIMS and GEMS, as well as EIRA, retrospectively gathered information regarding environmental and lifestyle factors. EIMS included incident cases to minimize recall bias, whereas GEMS was based on prevalent MS cases and recall bias may therefore be more substantial in this study. However, a validation study among women in the Nurses' Health Study found high correlations between recalled and measured past weight. ${ }^{29}$

There is a risk of misclassification when dichotomizing subjects into those with and without self-reported IM history. Because infection by other pathogens than EBV may cause an IM-like illness, subjects may unknowingly have had IM. However, this misclassification is not expected to differ between cases and controls. Furthermore, the risk of MS among subjects with a history of IM was in accordance with that of previous studies on past IM and MS risk. ${ }^{30}$ EBNA-1 antibody levels after MS onset

Table 5 OR with $95 \% \mathrm{Cl}$ of developing MS for subjects with different combinations of DRB1*15:01 status, BMI at age 20 years, and anti-EBNA-1 antibody levels

\begin{tabular}{|c|c|c|c|c|c|c|}
\hline BMI at age $20 \mathrm{y}, \mathrm{kg} / \mathrm{m}^{2}$ & High EBNA-1 antibody levels & $D R B 1 * 15: 01$ & $\mathrm{Ca} / \mathrm{co}^{\mathrm{a}}$ & OR $(95 \% \mathrm{Cl})^{\mathrm{b}}$ & RERI $(95 \% \mathrm{CI})$ & TotRERI $(95 \% \mathrm{Cl})$ \\
\hline$<25$ & - & - & $534 / 1,710$ & 1.0 (reference) & & \\
\hline$\geq 25$ & - & - & $89 / 186$ & $1.6(1.2-2.1)$ & & \\
\hline$<25$ & + & - & $1,230 / 1,511$ & $2.5(2.2-2.9)$ & & \\
\hline$\geq 25$ & + & - & $173 / 162$ & $3.3(2.6-4.2)$ & $1.2(0.4-2.1)$ & \\
\hline$<25$ & - & + & $470 / 554$ & $2.8(2.4-3.3)$ & & \\
\hline$\geq 25$ & - & + & $46 / 51$ & $3.1(2.0-4.7)$ & $1.5(0.3-2.6)$ & \\
\hline$<25$ & + & + & $1,964 / 752$ & $8.2(7.2-9.4)$ & $4.2(3.4-5.0)$ & \\
\hline$\geq 25$ & + & + & $314 / 77$ & $13.5(10.3-17.8)$ & & $8.6(5.0-12.1)$ \\
\hline
\end{tabular}

Abbreviations: $\mathrm{BMI}$ = body mass index; EPNA-1 = Epstein-Barr nuclear antigen 1; RERI = relative excess risk due to interaction; TotRERI = total relative excess risk due to interaction.

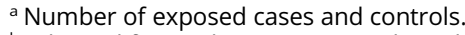

${ }^{\mathrm{b}}$ Adjusted for study, age, sex, residential area, ancestry, smoking, $A * 02: 01$, and IM history. 
Figure OR of developing MS for subjects with different combinations of $D R B 1 * 15: 01$, overweight/obesity $\left(>25 \mathrm{~kg} / \mathrm{m}^{2}\right)$, and IM history and EBNA-1 status, respectively, compared with unexposed DRB1*15:01-negative subjects
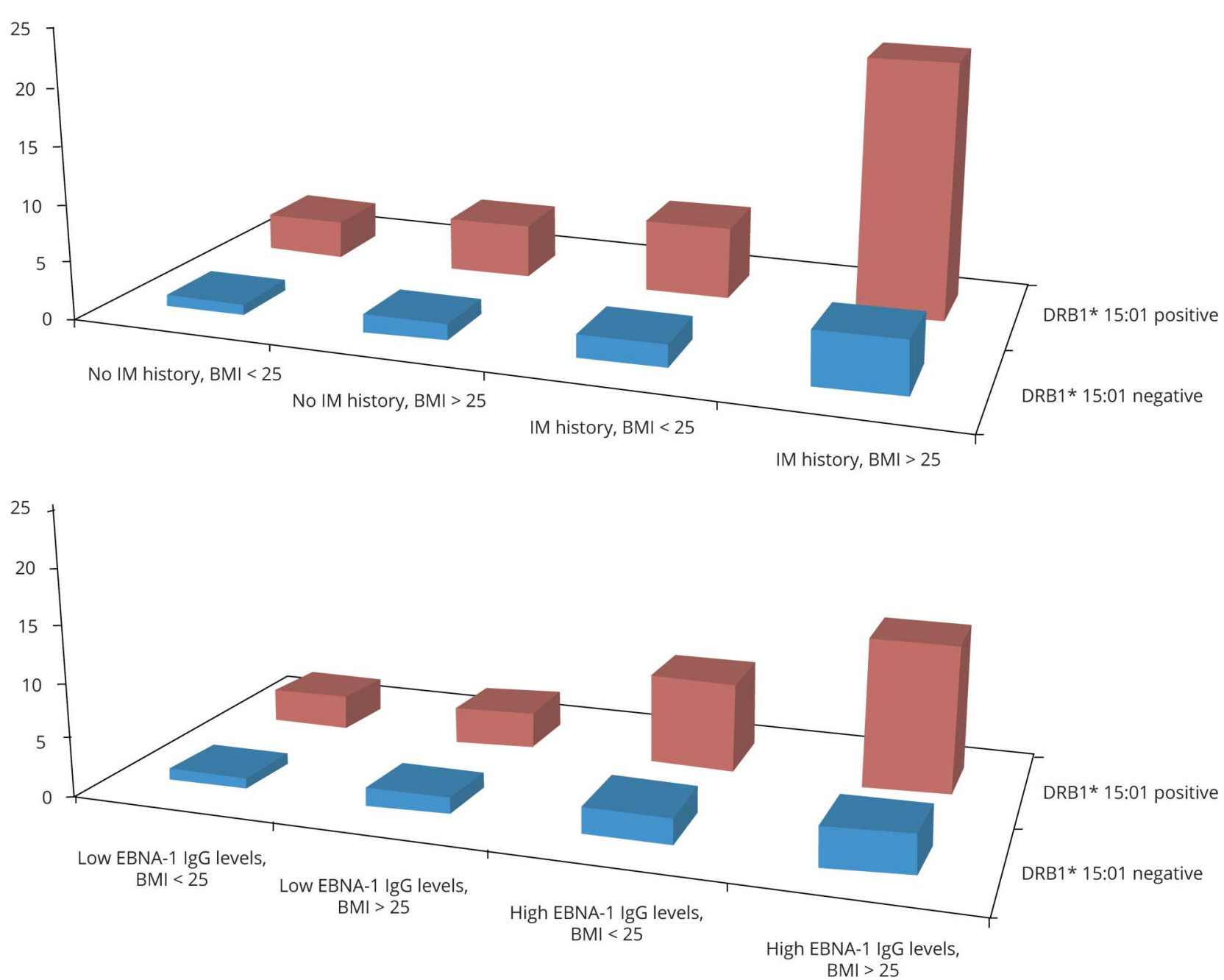

Based on data from tables 4 and 5.

were assumed to reflect levels before disease onset. This assumption is supported by findings that EBNA-1 antibody levels become elevated between 15 and 20 years before the clinical onset of MS and thereafter remain constant over time. ${ }^{31}$ Another concern is that the recruitment of cases and controls may introduce selection bias.

Because the Swedish health care system provides equal free of charge access to medical services for all Swedish citizens, most MS cases are referred to neurologic units. In both MS studies, selection bias was minimized by the population-based design. Although there was proportion of nonresponders among the controls, this bias is probably modest because the prevalence of lifestyle factors, such as smoking and socioeconomic status, among controls was consistent with that of the general population. ${ }^{32}$ Subjects who were excluded due to unknown IM history did not differ with regard to obesity at age 20 years, EBNA-1 antibody levels, or $D R B 1^{*} 15: 01$ status compared with those with known IM history. Furthermore, there were no significant differences with respect to age, sex, BMI at age 20 years, or IM history between those donated blood and those who did not, indicating that selection bias did not take place in this step.

The worldwide prevalence of overweight/obesity during childhood and young adulthood has increased over the last decades and has emerged as a serious public health concern. ${ }^{33}$ The increasing MS incidence in some countries may, at least to some extent, be explained by the increasing prevalence of obesity. Overweight and obesity are largely preventable, and intervention efforts need to be high priority to reduce long-term health consequences, including inflammatory diseases such as MS.

In summary, overweight/obesity in young adulthood acts synergistically with both aspects of EBV infection, predominantly among those with a genetic susceptibility to the disease. The obese state both induces a chronic immunemediated inflammation and affects the cellular immune 
response to infections, which may contribute to explain our findings. Our data reinforce the importance of intervention efforts against childhood and adolescent obesity to reduce MS incidence.

\section{Study funding}

The study was supported by grants from the Swedish Medical Research Council, the Swedish Research Council for Health, Working Life and Welfare, and the Swedish Brain Foundation. The funders had no role in study design, data collection, data analysis, data interpretation, or writing of the report.

\section{Disclosure}

A.K. Hedström, N. Brenner, and J. Butt report no disclosures. J. Hillert received honoraria for serving on advisory boards for Biogen, Celgene, Sanofi-Genzyme, Merck KGaA, Novartis, and Sandoz and speaker's fees from Biogen, Novartis, Merck KGaA, Teva, and Sanofi-Genzyme; he has served as PI for projects or received unrestricted research support from, Biogen Idec, Merck KGaA, Novartis, and Sanofi-Genzyme. T. Waterboer reports no disclosures. T. Olsson served on scientific advisory boards and received speaker honoraria Novartis, Merck, Biogen, Merck, and Genzyme; received from Novartis and Biogen; and receives unrestricted MS research support from Novartis, Genzyme, Biogen, Merck, the Swedish Research Council, and the Swedish Brain Foundation. L. Alfredsson received research support from the Swedish Medical Research Council, the Swedish Council for Health, Working Life and Welfare, and the Swedish Brain Foundation and has received speaker honoraria from Biogen Idec and Teva. Go to Neurology.org/NN for full disclosures.

\section{Publication history}

Received by Neurology: Neuroimmunology \& Neuroinflammation April 20, 2020. Accepted in final form September 11, 2020.

\begin{tabular}{lll}
\multicolumn{2}{l}{ Appendix } & Authors \\
\hline Name & Location & Contribution \\
\hline $\begin{array}{l}\text { Anna Karin } \\
\text { Hedström, } \\
\text { MD, PhD }\end{array}$ & $\begin{array}{l}\text { Karolinska } \\
\text { Institutet, } \\
\text { Stockholm, } \\
\text { Sweden }\end{array}$ & $\begin{array}{l}\text { Designed and conceptualized } \\
\text { the study; analyzed the data; } \\
\text { and drafted the manuscript }\end{array}$ \\
\hline $\begin{array}{l}\text { Nicole } \\
\text { Brenner, PhD }\end{array}$ & $\begin{array}{l}\text { German Cancer } \\
\text { Research Center, } \\
\text { Heidelberg }\end{array}$ & $\begin{array}{l}\text { Interpreted the data and } \\
\text { revised the manuscript }\end{array}$ \\
\hline $\begin{array}{l}\text { Julia Butt, } \\
\text { PhD }\end{array}$ & $\begin{array}{l}\text { German Cancer } \\
\text { Research Center, } \\
\text { Heidelberg }\end{array}$ & $\begin{array}{l}\text { Interpreted the data and } \\
\text { revised the manuscript }\end{array}$ \\
\hline $\begin{array}{l}\text { Jan Hillert, } \\
\text { MD, PhD }\end{array}$ & $\begin{array}{l}\text { Karolinska } \\
\text { Institutet, }\end{array}$ & $\begin{array}{l}\text { Designed and conceptualized } \\
\text { the study; interpreted the data; } \\
\text { and revised the manuscript }\end{array}$ \\
& $\begin{array}{l}\text { Stockholm, } \\
\text { Sweden }\end{array}$ & \\
\hline $\begin{array}{l}\text { Tim } \\
\text { Waterboer, } \\
\text { PhD }\end{array}$ & $\begin{array}{l}\text { German Cancer } \\
\text { Research Center, } \\
\text { Heidelberg }\end{array}$ & $\begin{array}{l}\text { Interpreted the data and } \\
\text { revised the manuscript }\end{array}$ \\
\hline
\end{tabular}

Appendix (continued)

\begin{tabular}{lll}
\hline Name & Location & Contribution \\
\hline $\begin{array}{l}\text { Tomas } \\
\text { Olsson, MD, } \\
\text { PhD }\end{array}$ & $\begin{array}{l}\text { Karolinska } \\
\text { Institutet, } \\
\text { Stockholm, } \\
\text { Sweden }\end{array}$ & $\begin{array}{l}\text { Designed and conceptualized } \\
\text { the study; interpreted the data; } \\
\text { and revised the manuscript }\end{array}$ \\
\hline $\begin{array}{l}\text { Lars } \\
\text { Alfredsson, } \\
\text { PhD }\end{array}$ & $\begin{array}{l}\text { Karolinska } \\
\text { Institutet, } \\
\text { Stockholm, } \\
\text { Sweden }\end{array}$ & $\begin{array}{l}\text { Designed and conceptualized } \\
\text { the study; interpreted the data; } \\
\text { and revised the manuscript }\end{array}$ \\
\hline
\end{tabular}

\section{References}

1. Moutsianas L, Jostins L, Beecham AH, et al. Class II HLA interactions modulate genetic risk for multiple sclerosis. Nat Genet 2015;47:1107-1113.

2. Hedström AK. Smoking and its interaction with genetics in MS etiology. Mult Scler 2019;25:180-186.

3. Tremlett H, Zhu F, Ascherio A, Munger KL. Sun exposure over the life course and associations with multiple sclerosis. Neurology 2018;90:e1191-e1199.

4. Simpson S Jr, der Mei IV, Taylor B. The role of vitamin D in multiple sclerosis: biology and biochemistry, epidemiology and potential roles in treatment. Med Chem 2018;14:129-143.

5. Munger KL, Chitnis T, Ascherio A. Body size and risk of MS in two cohorts of US women. Neurology 2009;73:1543-1550.

6. Hedström AK, Olsson T, Alfredsson L. High body mass index before age 20 is associated with increased risk for multiple sclerosis in both men and women. Mult Scler 2012;18:1334-1336.

7. Hedström AK, Huang J, Michel A, et al. High anti-EBNA-1 antibody levels and infectious mononucleosis act both independently and synergistically to increase multiple sclerosis risk. Front Neurol 2020;10:1368.

8. Hedström AK, Lima Bomfim I, Hillert J, Olsson T, Alfredsson L. Obesity interacts with infectious mononucleosis in risk of multiple sclerosis. Eur J Neurol 2015;22:578-e38.

9. Hedström AK, Bomfim IL, Barcellos LF, et al. Interaction between adolescent obesity and HLA risk genes in the development of multiple sclerosis. Neurology 2014;82:865-872.

10. Polman CH, Reingold SC, Edan G, et al. Diagnostic criteria for multiple sclerosis: 2005 revisions to the "McDonald Criteria." Ann Neurol 2005;58:840-846.

11. Polman $\mathrm{CH}$, Reingold SC, Banwell B, et al. Diagnostic criteria for multiple sclerosis 2010 revisions to the McDonald Criteria. Ann Neurol 2011;69:292-302.

12. Hillert J, Stawiarz L. The Swedish MS registry: clinical support tool and scientific resource. Acta Neurol Scand 2015;132:11-19.

13. Padyukov L, Silva C, Stolt P, Alfredsson L, Klareskog L. A gene-environment in teraction between smoking and shared epitope genes in HLA-DR provides a high risk of seropositive rheumatoid arthritis. Arthritis Rheum 2004;50:3085-3092.

14. Bäärnhielm M, Hedström AK, Kockum I, et al. Sunlight is associated with decreased multiple sclerosis risk: no interaction with human leukocyte antigen-DRB1*15. Eur J Neurol 2012;19:955-962.

15. International Multiple Sclerosis Genetics Consortium. The multiple sclerosis genomic map: role of peripheral immune cells and resident migraglia in susceptibility. Science 2019;365:eaav7188.

16. Dilthey A, Leslie S, Moutsianas L, et al. Multi-population classical HLA type imputation. PLoS Comput Biol 2013;9:e1002877.

17. Waterboer T, Sehr P, Michael KM, et al. Multiplex human papillomavirus serology based on in situ-purified glutathione s-transferase fusion proteins. Clin Chem 2005 51:1845-1853.

18. Tengvall K, Huang J, Hellström C, et al. Molecular mimicry between anoctamin 2 and Epstein-Barr virus nuclear antigen 1 associates with multiple sclerosis risk. Proc Nat Acad Sci USA 2019;116:16955-16960.

19. Sundqvist E, Sundström P, Lindén M, et al. Epstein-Barr virus and multiple sclerosis interactions with HLA. Genes Immun 2012;13:14-20.

20. Pearce N Analysis of matched case-control studies. BMJ 2016;25:352-i969.

21. Rothman KJ, Greenland S, Lash TL, editors. Modern Epidemiology. 3rd ed. Philadelphia: Lippincott Williams \& Wilkins; 2008.

22. VanderWeele TJ. Sufficient cause interactions and statistical interactions. Epidemiology 2009;20:6-13.

23. Subramanian V, Ferrante AW. Obesity, inflammation, and macrophages. Nestle Nutr Workshop Ser Pediatr Program 2009;63:151-159.

24. Lumeng CN, Bodzin JL, Deyoung SM, et al. Increased inflammatory properties of adipose tissue macrophages recruited during diet induced obesity. Diabetes 2007;56:16-23.

25. Matarese G, Procaccini C, De Rosa V. The intricate interface between immune and metabolic regulation: a role for leptin in the pathogenesis of multiple sclerosis? J Leukoc Biol 2008;84:893-899.

26. Procaccini C, Carbone F, Galgani M, et al. Obesity and susceptibility to autoimmune diseases. Expert Rev Clin Immunol 2011;7:287-294

27. Versini M, Jeandel PY, Rosenthal E, Shoenfeld Y. Obesity in autoimmune diseases: not a passive bystander. Autoimmun Rev 2014;13:981-1000.

28. Karlsson EA, Beck MA. The burden of obesity on infectious disease. Exp Biol Med 2010;235:1412-1424. 
29. Troy LM, Hunter DJ, Manson JE, Colditz GA, Stampfer MJ, Willett WC. The validity of recalled weight among younger women. Int J Obes Relat Metab Disord 1995;19:570-572.

30. Handel AE, Williamson AJ, Disanto G, Handunnetthi L, Giovannoni G, Ramagopalan SV. An updated meta-analysis of risk of multiple sclerosis following infectious mononucleosis. PLoS One 2010;5:e12496.

31. DeLorenze GN, Munger KL, Lennette ET, Orentreich N, Vogelman JH, Ascherio A. Epstein-Barr virus and multiple sclerosis. Evidence of association from a prospective study with long-term follow-up. Arch Neurol 2006;63: 839-844.

32. Internet-based information. Available at: scb.se. Accessed February 15, 2013

33. Abarca-Gomez L, Abdeen ZA, Hamid ZA, et al. Worldwide trends in body-mass index, underweight, overweight, and obesity from 1975 to 2016: a pooled analysis of 2416 population-based measurement studies in 128.9 million children, adolescents, and adults. Lancet 2017;390:2627-2642. 


\title{
Neurology \\ Neuroimmunology \& Neuroinflammation
}

\author{
Overweight/obesity in young adulthood interacts with aspects of EBV infection in MS \\ etiology \\ Anna Karin Hedström, Nicole Brenner, Julia Butt, et al. \\ Neurol Neuroimmunol Neuroinflamm 2021;8; \\ DOI 10.1212/NXI.0000000000000912
}

This information is current as of December 15, 2020

\section{Updated Information \& \\ Services}

References

Subspecialty Collections

Permissions \& Licensing

Reprints including high resolution figures, can be found at:

http://nn.neurology.org/content/8/1/e912.full.html

This article cites 31 articles, 4 of which you can access for free at: http://nn.neurology.org/content/8/1/e912.full.html\#\#ref-list-1

This article, along with others on similar topics, appears in the following collection(s):

Multiple sclerosis

http://nn.neurology.org//cgi/collection/multiple_sclerosis

Information about reproducing this article in parts (figures,tables) or in its entirety can be found online at:

http://nn.neurology.org/misc/about.xhtml\#permissions

Information about ordering reprints can be found online: http://nn.neurology.org/misc/addir.xhtml\#reprintsus

Neurol Neuroimmunol Neuroinflamm is an official journal of the American Academy of Neurology.

Published since April 2014, it is an open-access, online-only, continuous publication journal. Copyright

Copyright (C) 2020 The Author(s). Published by Wolters Kluwer Health, Inc. on behalf of the American

Academy of Neurology.. All rights reserved. Online ISSN: 2332-7812.

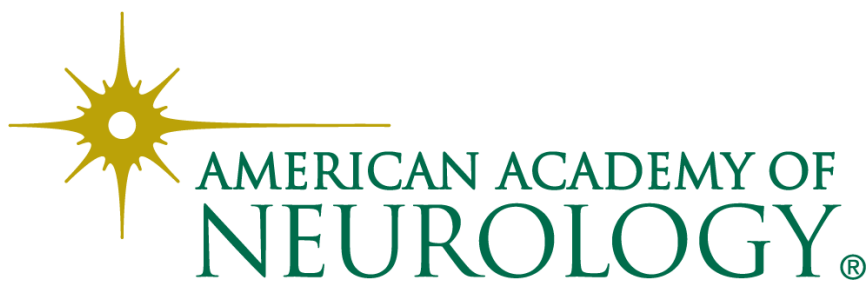

